\title{
Effects of Ethacrynic Acid (a New Saluretic Agent) on Renal Diluting and Concentrating Mechanisms: Evidence for Site of Action in the Loop of Henle*
}

\author{
Martin Goldberg, $\dagger$ Donna K. McCurdy, Elwood L. Foltz, and \\ Lewis W. Bluemle, JR.
}

(From the Chemical Section of the Department of Medicine, University of Pennsylvania School of Medicine, Philadelphia, Pa.)

Ethacrynic acid (MK-595) ${ }^{1}$ is a new orally active saluretic agent structurally unrelated to organomercurial or benzothiadiazine diuretics (2). Its biological properties in experimental animals were first studied by Baer, Russo, Michaelson, and Beyer $(3,4)$, who reported it to be a natriuretic drug more potent than chlorothiazide and suggested that it might have a novel mode of action. Clinically, its potency seems to be comparable to parenterally administered organomercurials, and it has been effective in patients previously refractory to other diuretics $(5,6)$. Because of the potential importance of this drug as an effective agent in the treatment of edema, the present study was undertaken to gain knowledge of the site or sites of action of the drug in the human kidney by determining its effects on urinary dilution and concentration.

Knowledge of the mechanisms of urinary concentration and dilution, recently reviewed by Gottschalk (7) and Ullrich, Kramer, and Boylan (8), has provided a basis for studying the locus of action of diuretics in the kidney of intact subjects. In the normal kidney, after reabsorption of approximately two-thirds of filtered sodium and water in isotonic proportions in the proximal convoluted tubule, the remaining urine may be

* Submitted for publication September 3, 1963; accepted October 8, 1963.

Supported by U. S. Public Health Service grants HE 07284-02, HE 0034014, and 8MO1 FR 40-03 and the C. Mahlon Kline Fund for the development of the Department of Medicine.

A preliminary report of this work will appear in the Proceedings of the 2nd International Congress of $\mathrm{Ne}-$ phrology (1).

$\dagger$ Awarded Research Career Development Award, National Institute of Arthritis and Metabolic Diseases (U. S. Public Health Service grant 5K3AM 18 582-02).

1 2-3 Dichloro-4-(2-methylenebutryl) phenoxyacetic acid. diluted or concentrated in the loop of Henle and distal nephron. In the ascending limb of Henle's loop, sodium is actively reabsorbed in excess of water, resulting in the production of a dilute urine in the tubular lumen before passage of the fluid from the ascending limb into the early distal tubule. Simultaneously, the solute reabsorbed in the loop is extruded into the renal medulla where the countercurrent multiplier system maintains a markedly hypertonic inner medulla. In the presence of antidiuretic hormone $(\mathrm{ADH})$, the final urine is concentrated by the passive movement of solute free water from isotonic urine in the collecting duct into the hypertonic medulla. In the absence of $\mathrm{ADH}$ (water diuresis), the hypotonic urine entering the early distal tubule is diluted further by the reabsorption of sodium at water-impermeable sites.

Thus urinary dilution or free water generation may occur at two sites in the nephron-the first site in the ascending limb of Henle's loop where the extracted solute is also involved in the mechanism of concentration of the final urine and the second site in the distal tubule [and possibly also the collecting duct $(9,10)]$ where dilution occurs by processes not directly related to the countercurrent mechanism.

Based on these concepts, a diuretic acting solely in the proximal tubule would be expected to enhance free water clearance $\left(\mathrm{C}_{\mathrm{H}_{2} \mathrm{O}}\right)$ during water diuresis because more sodium would be presented to both of the diluting sites for reabsorption, and also there would be relatively less $\mathrm{ADH}$-independent back diffusion of water from the collecting duct at high rates of urine flow (11). During hydropenia, a proximally acting drug would increase reabsorption of solute-free water by the collecting duct $\left(\mathrm{T}^{\mathrm{c}} \mathrm{H}_{2} \mathrm{O}\right)$ because of the availability of more osmotically active solute for 
transport into the medulla. Indeed, nonspecific osmotic or solute diuretics have been shown to increase $\mathrm{C}_{\mathrm{H}_{2} \mathrm{O}}(12-15)$ and $\mathrm{T}_{\mathrm{H}_{2} \mathrm{O}} \mathrm{c}(14,16-18)$ during water diuresis and hydropenia, respectively. Drugs acting in the distal nephron would have more variable effects. For example, chlorothiazide decreases $\mathrm{C}_{\mathrm{H}_{2} \mathrm{O}}$ in hydrated dogs (14) and humans (19), but does not decrease $\mathrm{T}^{\mathbf{c}}{ }_{\mathrm{H}_{2} \mathrm{O}}$ during hydropenia $(14,19)$. This suggests an action in the distal tubule at the second diluting site (14). To date, no natriuretic agent has been shown to lower both $\mathrm{C}_{\mathrm{H}_{2} \mathrm{O}}$ during water diuresis and $\mathrm{T}_{\mathrm{H}_{2} \mathrm{O}} \mathrm{C}_{\text {during hydropenia, the requirements }}$ necessary to invoke a site of action in the loop of Henle. The results of the present study strongly suggest a site of action of ethacrynic acid in Henle's loop, since this drug lowers both $\mathrm{C}_{\mathrm{H}_{2} \mathrm{O}}$ and $\mathrm{T}^{\mathrm{c}} \mathrm{H}_{2} \mathrm{O}$ over a wide range of solute excretion.

\section{Methods}

Twenty-seven acute studies were performed on eighteen healthy human volunteers and two patients with diabetes insipidus in the Clinical Research Center of the Hospital of the University of Pennsylvania. The effects of ethacrynic acid were observed both during water diuresis and during hydropenia.

\section{Water diuresis}

Ten experiments were performed in seven normal volunteers and two patients with diabetes insipidus. The subjects, who maintained their usual dietary intake, omitted fluids after midnight and reported for study at 8:30 to 9:00 a.m. After standing to empty the bladder, the subject assumed the recumbent position for the remainder of the study except to stand to void. In the two female patients with diabetes insipidus, an indwelling catheter was inserted, and urine was collected by using suprapubic pressure and bladder washout with air. A priming dose of inulin was administered, and a sustaining infusion of inulin in physiological saline was maintained at a rate of $1 \mathrm{ml}$ per minute throughout the experiment. After a 45-minute urine collection period, an oral load of tap water $(20 \mathrm{ml}$ per $\mathrm{kg}$ body weight $)$ was ingested in 20 to 30 minutes. Urine was collected every 15 to 20 minutes. After each urine collection, water was administered by mouth equal in volume to the volume of the urine passed during the previous period plus water at a rate of 0.7 to $1.0 \mathrm{ml}$ per minute to replace insensible loss. In the normal subjects, this procedure induced a state of sustained maximal water diuresis ("physiological diabetes insipidus"). When urine flow was stable, within $1 \mathrm{ml}$ per minute, for at least three consecutive periods, $150 \mathrm{mg}$ of ethacrynic acid was administered by mouth, and fluid replacement was continued after each period at a rate equal to that re- quired just before ingestion of the drug. Blood specimens were drawn about every 60 to 90 minutes at the mid-point of a collection period. The study was considered valid only if venipuncture had no observable effect on the sustained water diuresis (i.e., on urine flow or urine osmolality). Glomerular filtration rate (GFR) was estimated by inulin clearance $\left(\mathrm{C}_{\mathrm{In}}\right)$ in one control experiment and in four of the five studies involving the administration of ethacrynic acid. In the remainder of experiments during water diuresis, endogenous creatinine clearance $\left(\mathrm{C}_{\mathrm{Cr}_{r}}\right)$ was used to estimate GFR.

Two types of control experiments were performed. In two subjects, a sustained water diuresis without any drug administration was continued for 3 hours to assess the adequacy of the hydrating procedure in maintaining a steady state. In three subjects, after institution and maintenance of the sustained water diuresis as described above, an iv infusion of $3.75 \%$ mannitol was begun at a rate of $20 \mathrm{ml}$ per minute and maintained for 3 to 4 hours. These latter experiments were used to compare the effects of osmotic diuresis with those of ethacrynic acid on water diuresis.

\section{Hydropenia}

Seventeen experiments were performed in fourteen healthy male volunteers. The subjects were maintained on their usual diets. Food and fluids were omitted for 15 to 17 hours before the study which was begun at 8:30 to 9:00 a.m. No oral fluids were administered during the procedure except for $30 \mathrm{ml}$ of milk given with the oral administration of the drug. In each hydropenic experiment, $350 \mathrm{mU}$ of aqueous vasopressin was given intravenously over a period of 1 hour before the experiment. A priming dose of inulin was given, and an infusion of physiological saline containing inulin and vasopressin was infused at a constant rate of $1 \mathrm{ml}$ per minute. The quantities of these substances in the infusates provided a sustaining infusion of inulin for clearance determination and the administration of $350 \mathrm{mU}$ per hour of vasopressin. Blood specimens were obtained every hour. GFR was estimated with $\mathrm{C}_{\mathrm{In}}$ in two control studies and nine of the twelve studies involving cthacrynic acid. In the remainder, $\mathrm{C}_{\mathrm{Cr}_{r}}$ was used to estimate GFR. Four types of experimental protocols were utilized in the hydropenic studies.

A. Control solute diuresis. After one 60-minute or two 30 -minute collection periods, in three subjects an infusion of $10 \%$ mannitol in saline $(100$ mmoles $\mathrm{NaCl}$ per L) was started at a rate of $10 \mathrm{ml}$ per minute. Subsequently, the rate of infusion was gradually increased to give a progressively increasing rate of solute excretion. In two subjects, an infusion of $3 \% \mathrm{NaCl}$ was started instead of the mannitol at a rate of $10 \mathrm{ml}$ per minute, and the rate was also gradually increased. In hoth types of control experiments, the infusions were continued until rates of solute clearance $\left(\mathrm{C}_{\mathrm{osm}}\right)$ were between 20 and $40 \mathrm{ml}$ per minute.

B. Ethacrynic acid alone (administered at low initial rates of solute excretion). In four hydropenic sub- 
ETHACRYNIC ACID: EVIDENCE FOR SITE OF ACTION IN LOOP OF HENLE

TABLE I

Protocols of three experiments during maximal water diuresis*

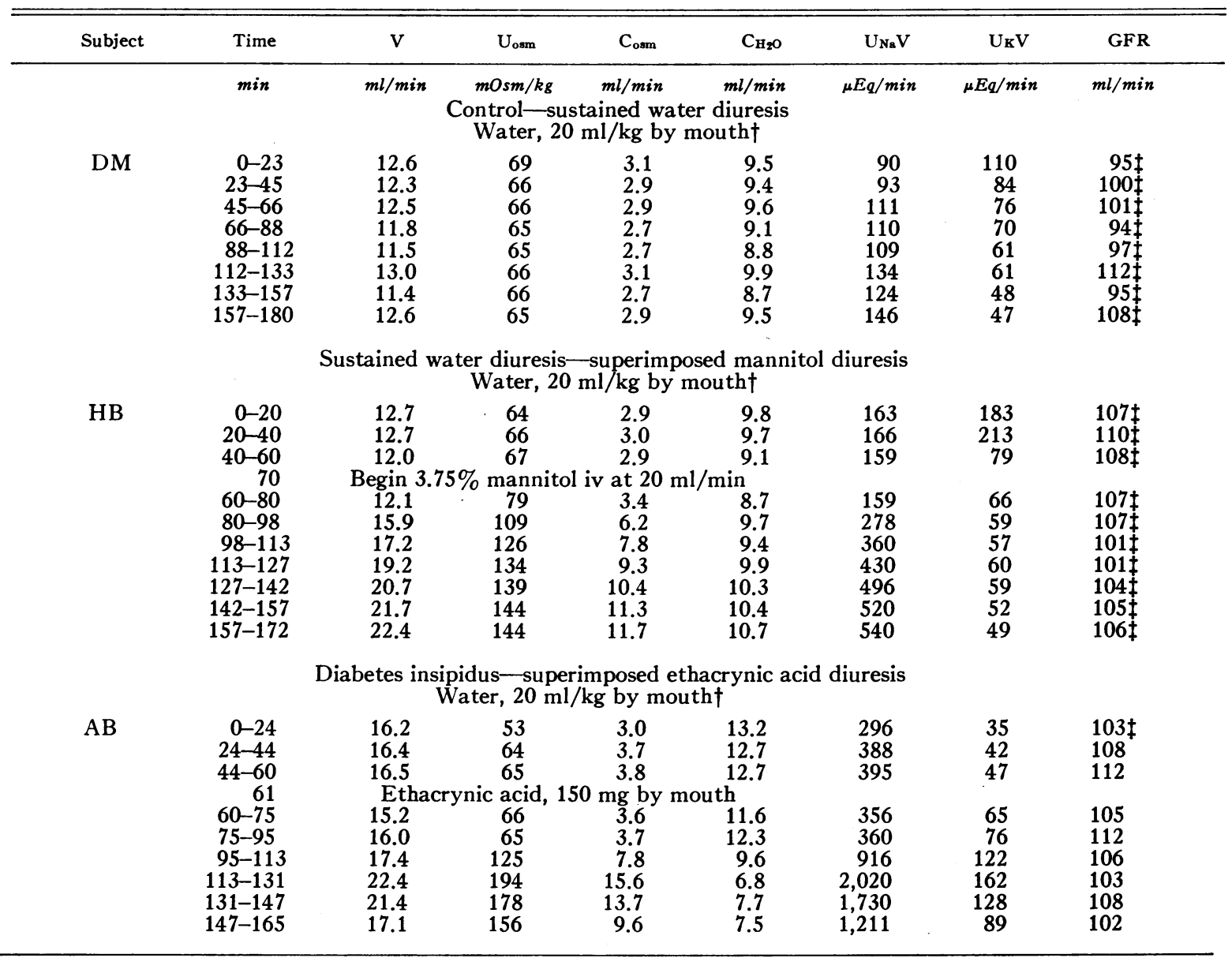

* Abbreviations: $\mathrm{V}=$ urine flow, $\mathrm{U}_{\mathrm{osm}}=$ urine osmolality, $\mathrm{C}_{\mathrm{osm}}=$ osmolar clearance, $\mathrm{C}_{\mathrm{H}, \mathrm{O}}=$ free water clearance, $\mathrm{U}_{\mathrm{Na}} \mathrm{V}=$ sodium excretion, $\mathrm{U}_{\mathrm{K}} \mathrm{V}=$ potassium excretion, and $\mathrm{GFR}=$ glomerular filtration rate.

† Subsequently, water was given orally after each collection period in amounts equal to urine volume of the previous period plus 0.7 to $1.0 \mathrm{ml}$ per minute for insensible loss.

$\ddagger$ Clearance of endogenous creatinine. All other values for GFR represent inulin clearance.

jects, after making suitable control urine collections, $150 \mathrm{mg}$ of ethacrynic acid was administered orally, and the urine was collected every 15 to 30 minutes thereafter for approximately 4 hours.

C. Ethacrynic acid diuresis with superimposed solute diuresis. In four hydropenic subjects, the experiments were begun with the administration of ethacrynic acid as above. When the effects of the drug were definitely established (i.e., after a significant rise in urine flow and solute excretion), an infusion of $10 \%$ mannitol in saline (100 mmoles $\mathrm{NaCl}$ per $\mathrm{L}$ ) at a rate of $10 \mathrm{ml}$ per minute was started in two subjects, and an infusion of $3 \% \mathrm{NaCl}$ at a rate of $10 \mathrm{ml}$ per minute was started in two other subjects. These infusions were continued for 2 to 3 hours.

D. Solute diuresis with superimposed ethacrynic acid diuresis (ethacrynic acid administered at high initial rates of solute excretion). These studies were performed in four hydropenic subjects. The experiments were begun in a similar manner to the control studies with $10 \%$ mannitol in saline. When solute clearance during the osmotic diuresis was between 10 and $20 \mathrm{ml}$ per minute, $150 \mathrm{mg}$ of ethacrynic acid was given orally, and the rate of the mannitol-saline infusion was maintained through the remainder of the experiment at the same rate as before drug administration.

\section{Chemical methods and calculations}

All of the urine and blood specimens were analyzed for sodium and potassium by lithium internal standard flame photometry, chlorides were analyzed by a chloridometric technique (20), creatinine by the method of Bonsnes and Taussky (21), and osmolality by a Fiske osmometer. Inulin in plasma and urine was determined 
TABLE II

Summary of studies during water diuresis*

\begin{tabular}{|c|c|c|c|c|c|c|c|c|c|}
\hline \multicolumn{2}{|c|}{ Subject } & $\mathrm{V}$ & Uosm & $\mathrm{C}_{\mathrm{H}_{2} \mathrm{O}}$ & $\mathrm{C}_{\mathrm{osm}}$ & $\mathrm{UNaV}_{\mathrm{Na}}$ & $\mathrm{UclV}$ & UkV & GFR \\
\hline \multirow{2}{*}{\multicolumn{2}{|c|}{ Normal }} & $\mathrm{ml} / \mathrm{min}$ & $\mathrm{mOsm} / \mathrm{kg}$ & $\mathrm{ml} / \mathrm{min}$ & $m l / \min$ & $\mu E q / \min$ & $\mu E q / \min$ & $\mu E q / \min$ & $m l / m i n$ \\
\hline & & \multicolumn{7}{|c|}{ Sustained water diuresis-superimposed mannitol diuresis } & \\
\hline $\mathrm{HB}$ & ${ }_{2}^{1 \dagger}$ & $\begin{array}{l}12.5 \\
22.4\end{array}$ & $\begin{array}{r}66 \\
144\end{array}$ & $\begin{array}{r}9.6 \\
10.7\end{array}$ & $\begin{array}{r}2.9 \\
11.7\end{array}$ & $\begin{array}{l}163 \\
540\end{array}$ & $\begin{array}{l}190 \\
957\end{array}$ & $\begin{array}{l}80 \\
49\end{array}$ & $\begin{array}{l}108 \ddagger \\
106 \ddagger\end{array}$ \\
\hline RR & $\begin{array}{l}1 \\
2\end{array}$ & $\begin{array}{l}13.1 \\
21.1\end{array}$ & $\begin{array}{r}66 \\
124\end{array}$ & $\begin{array}{l}10.0 \\
11.8\end{array}$ & $\begin{array}{l}3.1 \\
9.3\end{array}$ & $\begin{array}{l}131 \\
274\end{array}$ & $\begin{array}{l}140 \\
277\end{array}$ & $\begin{array}{l}57 \\
55\end{array}$ & $\begin{array}{l}108 \\
125\end{array}$ \\
\hline $\mathrm{EH}$ & $\begin{array}{l}1 \\
2\end{array}$ & $\begin{array}{l}12.1 \\
28.8\end{array}$ & $\begin{array}{r}80 \\
131\end{array}$ & $\begin{array}{r}8.6 \\
14.9\end{array}$ & $\begin{array}{r}3.5 \\
13.9\end{array}$ & $\begin{array}{l}181 \\
576\end{array}$ & $\begin{array}{l}135 \\
453\end{array}$ & $\begin{array}{r}100 \\
53\end{array}$ & $\begin{array}{l}127 \ddagger \\
153 \ddagger\end{array}$ \\
\hline
\end{tabular}

Sustained water diuresis-superimposed ethacrynic acid diuresis

\begin{tabular}{|c|c|c|c|c|c|c|c|c|c|}
\hline \multicolumn{10}{|c|}{ Normal } \\
\hline $\mathrm{EF}$ & $\begin{array}{l}1 \\
2 \\
3\end{array}$ & $\begin{array}{l}15.1 \\
25.5 \\
21.7\end{array}$ & $\begin{array}{r}57 \\
185 \\
179\end{array}$ & $\begin{array}{r}11.9 \\
8.2 \\
7.4\end{array}$ & $\begin{array}{r}3.2 \\
17.3 \\
14.3\end{array}$ & $\begin{array}{r}151 \\
2,150 \\
1,750\end{array}$ & $\begin{array}{r}144 \\
2,240 \\
1,820\end{array}$ & $\begin{array}{l}120 \\
191 \\
174\end{array}$ & $\begin{array}{r}109 \\
102 \\
97\end{array}$ \\
\hline LB & $\begin{array}{l}1 \\
2 \\
3\end{array}$ & $\begin{array}{l}14.1 \\
23.9 \\
13.6\end{array}$ & $\begin{array}{r}62 \\
185 \\
135\end{array}$ & $\begin{array}{r}10.9 \\
7.6 \\
6.8\end{array}$ & $\begin{array}{r}3.2 \\
16.3 \\
6.8\end{array}$ & $\begin{array}{r}193 \\
2,110 \\
738\end{array}$ & $\begin{array}{r}205 \\
2,080 \\
746\end{array}$ & $\begin{array}{r}64 \\
116 \\
54\end{array}$ & $\begin{array}{r}106 \\
110 \\
96\end{array}$ \\
\hline RR & $\begin{array}{l}1 \\
2\end{array}$ & $\begin{array}{l}16.4 \\
20.2\end{array}$ & $\begin{array}{r}65 \\
174\end{array}$ & $\begin{array}{r}12.6 \\
7.7\end{array}$ & $\begin{array}{r}3.8 \\
12.5\end{array}$ & $\begin{array}{r}144 \\
1,460\end{array}$ & $\begin{array}{r}163 \\
1,640\end{array}$ & $\begin{array}{l}44 \\
65\end{array}$ & $\begin{array}{r}103 \\
85\end{array}$ \\
\hline \multicolumn{10}{|c|}{ Diabetes insipidus } \\
\hline $\mathrm{AB}$ & $\begin{array}{l}1 \\
2\end{array}$ & $\begin{array}{l}16.4 \\
22.4\end{array}$ & $\begin{array}{r}61 \\
194\end{array}$ & $\begin{array}{r}12.9 \\
6.8\end{array}$ & $\begin{array}{r}3.5 \\
15.6\end{array}$ & $\begin{array}{r}360 \\
2,020\end{array}$ & $\begin{array}{r}341 \\
2,190\end{array}$ & $\begin{array}{r}41 \\
162\end{array}$ & $\begin{array}{l}110 \\
103\end{array}$ \\
\hline LG & $\begin{array}{l}1 \\
2 \\
3\end{array}$ & $\begin{array}{l}11.8 \\
22.0 \\
14.5\end{array}$ & $\begin{array}{r}51 \\
170 \\
121\end{array}$ & $\begin{array}{l}9.7 \\
9.4 \\
7.7\end{array}$ & $\begin{array}{r}2.1 \\
12.6 \\
5.4\end{array}$ & $\begin{array}{r}82 \\
1,700 \\
538\end{array}$ & $\begin{array}{r}43 \\
2,180 \\
759\end{array}$ & $\begin{array}{l}142 \\
354 \\
200\end{array}$ & $\begin{array}{r}111 \ddagger \\
109 \ddagger \\
83 \ddagger\end{array}$ \\
\hline
\end{tabular}

* Abbreviations as in Table I. $\mathrm{U}_{\mathrm{Cl}} \mathrm{V}=$ chloride excretion.

$\dagger$ For all studies during water diuresis, 1 represents the mean value of three control periods during sustained water diuresis just before administration of mannitol or ethacrynic acid, 2 represents the values obtained during the maximal diuretic response to mannitol or ethacrynic acid, and 3 represents the values obtained during maximal decrease in $\mathrm{C}_{\mathrm{H}_{2} \mathrm{O}}$ after ethacrynic acid when this did not coincide with maximal solute diuresis.

¥ Clearance of endogenous creatinine. All other values for GFR represent inulin clearance.

by the method of Walser, Davidson, and Orloff (22). $\mathrm{C}_{\mathrm{osm}}, \mathrm{C}_{\mathrm{H}_{2} \mathrm{O}}$, and $\mathrm{T}_{\mathrm{H}_{2} \mathrm{O}}^{\mathrm{c}}$ were calculated by the following formulas: $\mathrm{C}_{\mathrm{osm}}=\mathrm{U}_{\mathrm{osm}} \mathrm{V} / \mathrm{P}_{\mathrm{osm}}, \mathrm{C}_{\mathrm{H}: \mathrm{O}}=\mathrm{V}-\mathrm{C}_{\mathrm{osm}}$ during water diuresis, and $\mathrm{T}_{\mathrm{H}_{2} \mathrm{O}}^{\mathrm{c}}=\mathrm{C}_{\mathrm{osm}}-\mathrm{V}$ during hydropenia, where $\mathrm{U}_{\mathrm{osm}}=$ osmolality of urine (mOsm per $\left.\mathrm{kg}\right), \mathrm{P}_{\mathrm{osm}}$ = osmolality of serum $(\mathrm{mOsm}$ per $\mathrm{kg})$, and $\mathrm{V}=$ urine flow ( $\mathrm{ml}$ per minute).

\section{Results}

\section{Studies in hydrated subjects}

Control studies. Effects of osmotic diuresis superimposed on water diuresis. The first two protocols in Table I show one experiment in which maximal diuresis was sustained for 3 hours and one typical experiment in which mannitol diuresis was superimposed on sustained water diuresis. The first experiment illustrates the adequacy of the hydrating procedure in maintaining a steady state of hydration with regard to $U_{o s m}, V$, and $\mathrm{C}_{\mathrm{H}_{2} \mathrm{O}}$. In the experiment with mannitol, as $\mathrm{C}_{\text {osm }}$ increased from 2.9 to $11.7 \mathrm{ml}$ per minute, there was a progressive rise in $\mathrm{C}_{\mathrm{H}_{2} \mathrm{O}}$ from a mean control value of $9.6 \mathrm{ml}$ per minute to $10.7 \mathrm{ml}$ per minute. Qualitatively similar changes in $\mathrm{C}_{\mathrm{H}_{2} \mathrm{O}}$ were observed in the other two subjects during water diuresis and superimposed mannitol diuresis (Table II). The greatest increment in $\mathrm{C}_{\mathrm{H}_{2} \mathrm{O}}$ occurred in subject $\mathrm{EH}$ in whom $\mathrm{C}_{\mathrm{H}_{2} \mathrm{O}}$ increased from 8.6 to $14.9 \mathrm{ml}$ per minute, while $\mathrm{C}_{\text {osm }}$ increased from 3.5 to $13.9 \mathrm{ml}$ per minute. These results agree with the data of other investigators who studied the effects of mannitol diuresis in hydrated subjects or animals (12-15).

Effects of ethacrynic acid in normal hydrated subjects and patients with diabetes insipidus. Figure 1 presents the effects of ethacrynic acid on $\mathrm{V} ; \mathrm{C}_{\mathrm{osm}} ; \mathrm{C}_{\mathrm{H}_{2} \mathrm{O}} ; \mathrm{U}_{\mathrm{osm}} / \mathrm{P}_{\mathrm{osm}}$; sodium, chloride, and potassium excretion; and $\mathrm{C}_{\text {In }}$ in a typical experi- 

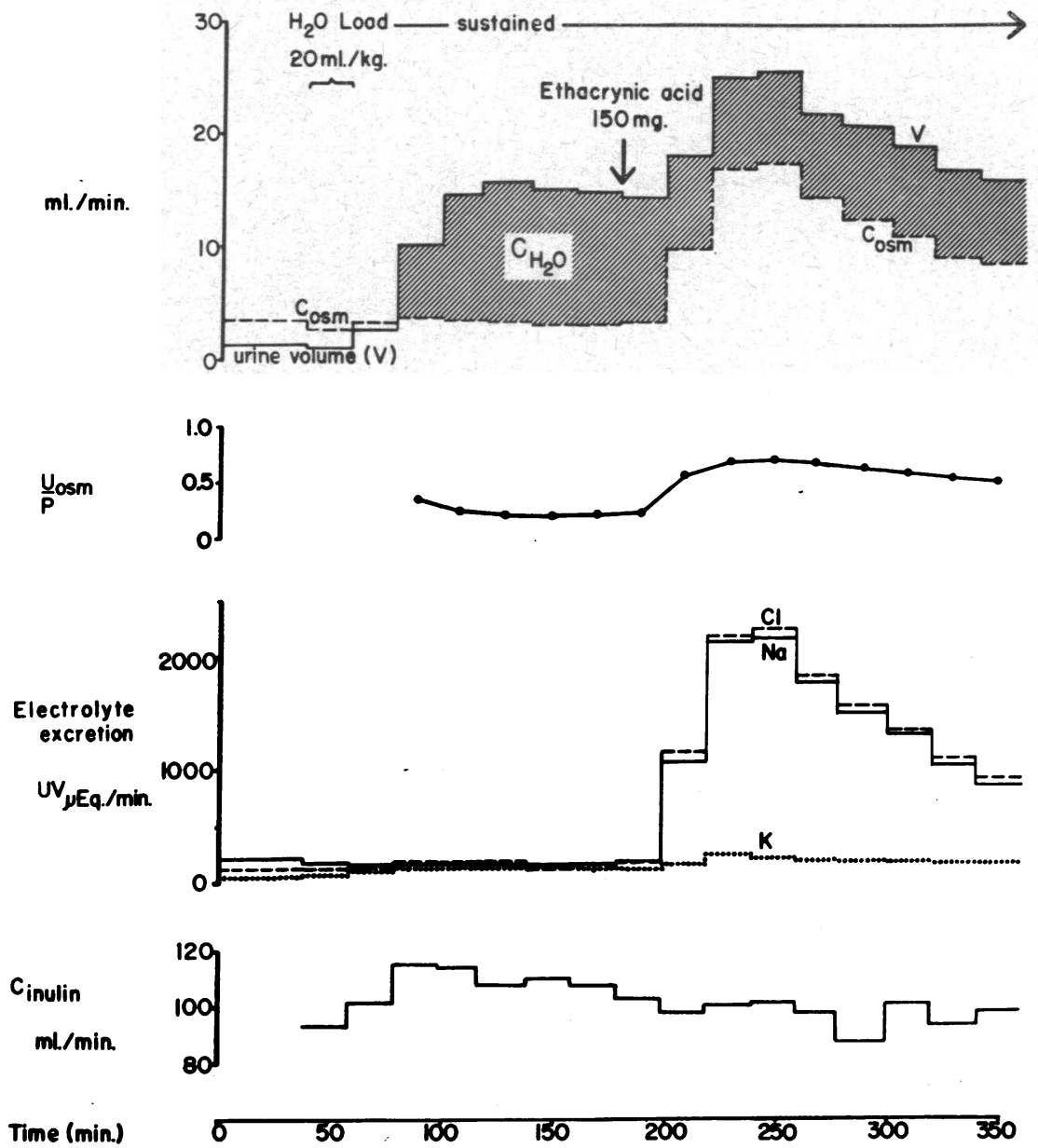

Fig. 1. Ethacrynic ACId in a Normal maximally hydrated subject (ef). Effects on urine flow $(V)$, free water clearance $\left(\mathrm{C}_{\mathrm{H}_{20}}\right)$, osmolar clearance $\left(\mathrm{C}_{\mathrm{osm}}\right)$, electrolyte excretion, and inulin clearance. Before administration of the drug, the control value for $\mathrm{C}_{\mathrm{H}_{2} \mathrm{O}}$ was $11.9 \mathrm{ml}$ per minute. At the peak of saluresis, $\mathrm{C}_{\mathrm{B}_{20}}$ fell to $8.2 \mathrm{ml}$ per minute and subsequently reached a minimal value of $7.9 \mathrm{ml}$ per minute. $U / P$ osm $=$ urine osmolality/serum osmolality.

ment on a normal hydrated subject. The effects of the drug in diabetes insipidus are presented in the third protocol in Table I, and all studies during water diuresis are summarized in Table II.

Results were essentially the same in both subjects with "physiological" diabetes insipidus and the patients with true diabetes insipidus. Twenty to 40 minutes after ingestion of ethacrynic acid, $\mathrm{C}_{\text {osm }}$ and sodium and chloride excretion began to increase. The peak of the saluresis occurred at 60 to 90 minutes when the sodium and chloride excretion rates were 1,460 to 2,150 and 1,640 to $2,240 \mu \mathrm{Eq}$ per minute, respectively. These rates of natriuresis correspond to 12.8 to $15.2 \%$ of the estimated filtered load of sodium. In contrast to the effects of mannitol diuresis, however, there was a distinct decrease in $\mathrm{C}_{\mathrm{H}_{2} \mathrm{O}}$ after ethacrynic acid. As illustrated in Table II, $\mathbf{C}_{\mathbf{H}_{2} \mathrm{O}}$ decreased in all experiments in which ethacrynic acid diuresis was superimposed on water diuresis. $\mathrm{C}_{\mathrm{H}_{2} \mathrm{O}}$ fell more than $4 \mathrm{ml}$ per minute in four of the five experiments, the maximal fall in $\mathrm{C}_{\mathrm{H}_{2} \mathrm{O}}$ ranging from 2.0 to $6.1 \mathrm{ml}$ per minute. Although $\mathrm{C}_{\mathrm{H}_{2} \mathrm{O}}$ approached its minimal value during the peak of saluresis, it continued to fall in three of the five subjects even as solute excretion was decreasing, so that the minimal value for $\mathrm{C}_{\mathrm{H}_{2} \mathrm{O}}$ occurred during the descending limb of the saluresis at values 
of $\mathrm{C}_{\mathrm{osm}}$ varying from 14.3 to $5.4 \mathrm{ml}$ per minute. In one normal subject (RR) and in one patient with diabetes insipidus $(\mathrm{AB})$, the maximal $\mathrm{C}_{\text {osm }}$ and the minimal $\mathrm{C}_{\mathrm{H}_{2} \mathrm{O}}$ occurred simultaneously.

Although the major rise in solute excretion caused by ethacrynic acid consisted of a marked natriuresis and chloruresis, appreciable increases in the excretion of potassium, titratable acid, and ammonium also occurred. As seen in Table II, those subjects with the highest base-line potassium excretion exhibited the highest potassium excretion during the height of diuresis. In four studies, maximal potassium excretion varied be- tween 65 and $191 \mu \mathrm{Eq}$ per minute, and in patient LG, with the highest control excretion, it rose to $354 \mu \mathrm{Eq}$ per minute. At the peak of solute diuresis caused by ethacrynic acid in three hydrated subjects ( $L B, E F$, and $R R$ ), urinary excretion of titratable acid rose to a mean value of $47 \mu \mathrm{Eq}$ per minute from a mean control value of $29 \mu \mathrm{Eq}$ per minute, urinary ammonium excretion rose to a mean value of $48 \mu \mathrm{Eq}$ per minute from a mean control value of $34 \mu \mathrm{Eq}$ per minute, and urinary $\mathrm{pH}$ fell from 6.04 to 5.64 .

In most of the hydrated subjects there was a tendency for GFR to fall with time after ad-

TABLE III

Studies during hydropenia in normal subjects*

\begin{tabular}{|c|c|c|c|c|c|c|c|c|c|}
\hline \multicolumn{2}{|c|}{ Subject } & $\mathrm{V}$ & $\mathrm{U}_{\mathrm{osm}}$ & $\mathrm{C}_{\mathrm{osm}}$ & $\mathrm{T}^{\mathrm{e}_{2}} \mathrm{O}$ & $\mathrm{UNaV}_{\mathrm{Na}}$ & $\mathrm{UclV}$ & $\mathrm{UKV}_{\mathbf{K}}$ & GFR \\
\hline \multicolumn{10}{|c|}{$\begin{array}{l}\text { A. Control solute diuresis } \\
10 \% \text { mannitol in saline }\end{array}$} \\
\hline LB & $\begin{array}{l}1 \dagger \\
2 \\
3\end{array}$ & $\begin{array}{r}0.7 \\
6.7 \\
24.2\end{array}$ & $\begin{array}{r}1,120 \\
548 \\
391\end{array}$ & $\begin{array}{r}2.6 \\
12.1 \\
30.7\end{array}$ & $\begin{array}{l}1.9 \\
6.4 \\
6.5\end{array}$ & $\begin{array}{r}154 \\
503 \\
1,770\end{array}$ & $\begin{array}{r}163 \\
520 \\
1,780\end{array}$ & $\begin{array}{l}115 \\
153 \\
205\end{array}$ & $\begin{array}{l}141 \ddagger \\
121 \ddagger \\
124 \ddagger\end{array}$ \\
\hline RK & $\begin{array}{l}1 \\
2 \\
3\end{array}$ & $\begin{array}{r}1.3 \\
7.2 \\
34.5\end{array}$ & $\begin{array}{l}887 \\
568 \\
376\end{array}$ & $\begin{array}{r}4.0 \\
14.2 \\
41.1\end{array}$ & $\begin{array}{l}2.7 \\
7.0 \\
6.6\end{array}$ & $\begin{array}{r}225 \\
626 \\
2,540\end{array}$ & $\begin{array}{r}170 \\
538 \\
2,600\end{array}$ & $\begin{array}{r}63 \\
82 \\
466\end{array}$ & $\begin{array}{l}177 \ddagger \\
175 \\
141\end{array}$ \\
\hline FB & $\begin{array}{l}1 \\
2 \\
3\end{array}$ & $\begin{array}{r}0.6 \\
6.4 \\
14.6\end{array}$ & $\begin{array}{r}1,100 \\
586 \\
456\end{array}$ & $\begin{array}{r}2.1 \\
12.4 \\
21.9\end{array}$ & $\begin{array}{l}1.5 \\
6.0 \\
7.3\end{array}$ & $\begin{array}{l}512 \\
360 \\
875\end{array}$ & $\begin{array}{r}89 \\
409 \\
995\end{array}$ & $\begin{array}{l}122 \\
166 \\
259\end{array}$ & $\begin{array}{l}118 \ddagger \\
109 \\
112\end{array}$ \\
\hline \multicolumn{10}{|c|}{$3 \% \mathrm{NaCl}$} \\
\hline PL & $\begin{array}{l}1 \\
2 \\
3\end{array}$ & $\begin{array}{r}0.9 \\
4.1 \\
16.0\end{array}$ & $\begin{array}{r}1,120 \\
725 \\
528\end{array}$ & $\begin{array}{r}3.6 \\
10.1 \\
27.2\end{array}$ & $\begin{array}{r}2.7 \\
6.0 \\
11.2\end{array}$ & $\begin{array}{r}238 \\
1,170 \\
3,720\end{array}$ & $\begin{array}{r}171 \\
1,090 \\
3,820\end{array}$ & $\begin{array}{r}47 \\
114 \\
393\end{array}$ & $\begin{array}{l}133 \ddagger \\
155 \ddagger \\
123 \ddagger\end{array}$ \\
\hline $\mathrm{CS}$ & $\begin{array}{l}1 \\
2 \\
3\end{array}$ & $\begin{array}{r}1.1 \\
5.3 \\
20.5\end{array}$ & $\begin{array}{r}1,020 \\
650 \\
480\end{array}$ & $\begin{array}{r}3.7 \\
11.6 \\
31.6\end{array}$ & $\begin{array}{r}2.6 \\
6.3 \\
11.1\end{array}$ & $\begin{array}{r}266 \\
1,230 \\
4,460\end{array}$ & $\begin{array}{r}215 \\
1,400 \\
4,780\end{array}$ & $\begin{array}{r}69 \\
152 \\
368\end{array}$ & $\begin{array}{l}109 \ddagger \\
131 \ddagger \\
162 \ddagger\end{array}$ \\
\hline \multicolumn{10}{|c|}{ B. Ethacrynic acid alone } \\
\hline SB & $\frac{1 \S}{2}$ & $\begin{array}{r}0.7 \\
11.7\end{array}$ & $\begin{array}{r}1,050 \\
297\end{array}$ & $\begin{array}{r}2.5 \\
12.3\end{array}$ & $\begin{array}{l}1.8 \\
0.6\end{array}$ & $\begin{array}{r}144 \\
1,510\end{array}$ & $\begin{array}{r}119 \\
1,640\end{array}$ & $\begin{array}{r}67 \\
132\end{array}$ & $\begin{array}{l}129 \ddagger \\
131\end{array}$ \\
\hline SW & $\begin{array}{l}1 \\
2 \\
3\end{array}$ & $\begin{array}{r}0.9 \\
10.5 \\
8.2\end{array}$ & $\begin{array}{l}952 \\
332 \\
321\end{array}$ & $\begin{array}{r}2.8 \\
12.0 \\
9.0\end{array}$ & $\begin{array}{l}1.9 \\
1.5 \\
0.8\end{array}$ & $\begin{array}{r}183 \\
1,400 \\
1,100\end{array}$ & $\begin{array}{r}142 \\
1,600 \\
1,210\end{array}$ & $\begin{array}{r}73 \\
166 \\
124\end{array}$ & $\begin{array}{l}159 \\
130 \\
158\end{array}$ \\
\hline $\mathrm{RB}$ & $\begin{array}{l}1 \\
2 \\
3\end{array}$ & $\begin{array}{l}0.9 \\
8.5 \\
7.0\end{array}$ & $\begin{array}{l}868 \\
317 \\
320\end{array}$ & $\begin{array}{l}2.8 \\
9.6 \\
8.0\end{array}$ & $\begin{array}{l}1.9 \\
1.1 \\
1.0\end{array}$ & $\begin{array}{r}170 \\
1,070 \\
863\end{array}$ & $\begin{array}{r}187 \\
1,220 \\
985\end{array}$ & $\begin{array}{r}98 \\
213 \\
185\end{array}$ & $\begin{array}{l}128 \ddagger \\
105 \\
112\end{array}$ \\
\hline $\mathrm{EH}$ & $\begin{array}{l}1 \\
2 \\
3\end{array}$ & $\begin{array}{r}1.4 \\
11.6 \\
6.4\end{array}$ & $\begin{array}{l}866 \\
322 \\
334\end{array}$ & $\begin{array}{r}4.1 \\
13.2 \\
7.0\end{array}$ & $\begin{array}{l}2.7 \\
1.6 \\
0.6\end{array}$ & $\begin{array}{r}273 \\
1,520 \\
767\end{array}$ & $\begin{array}{r}198 \\
1,620 \\
842\end{array}$ & $\begin{array}{l}149 \\
167 \\
106\end{array}$ & $\begin{array}{r}142 \\
108 \\
85\end{array}$ \\
\hline
\end{tabular}

* Abbreviations as in Table I. $\quad \mathrm{T}^{\mathrm{c}}{ }_{\mathrm{H}_{2} \mathrm{O}}=$ tubular reabsorption of solute-free water. $\mathrm{U}_{\mathrm{Cl}} \mathrm{V}=$ chloride excretion.

$\dagger$ For studies with control solute diuresis, 1 refers to values obtained before administration of $10 \%$ mannitol in saline or $3 \%$ salt, 2 refers to values obtained during solute diuresis at intermediate values of $C_{o s m}$, and 3 refers to values obtained at high values of $C_{\text {osm }}$.

\pm Clearance of endogenous creatinine. All other values for GFR represent inulin clearance.

$\$$ For studies with ethacrynic acid alone, 1 refers to values before drug administration, 2 refers to values during the peak of diuretic response, and 3 refers to values af ter the peak of diuretic response during which minimal $\mathrm{T}^{\mathrm{c}} \mathrm{H}_{2} \mathrm{O}$ was obtained, if the latter did not occur during the peak of diuresis. 


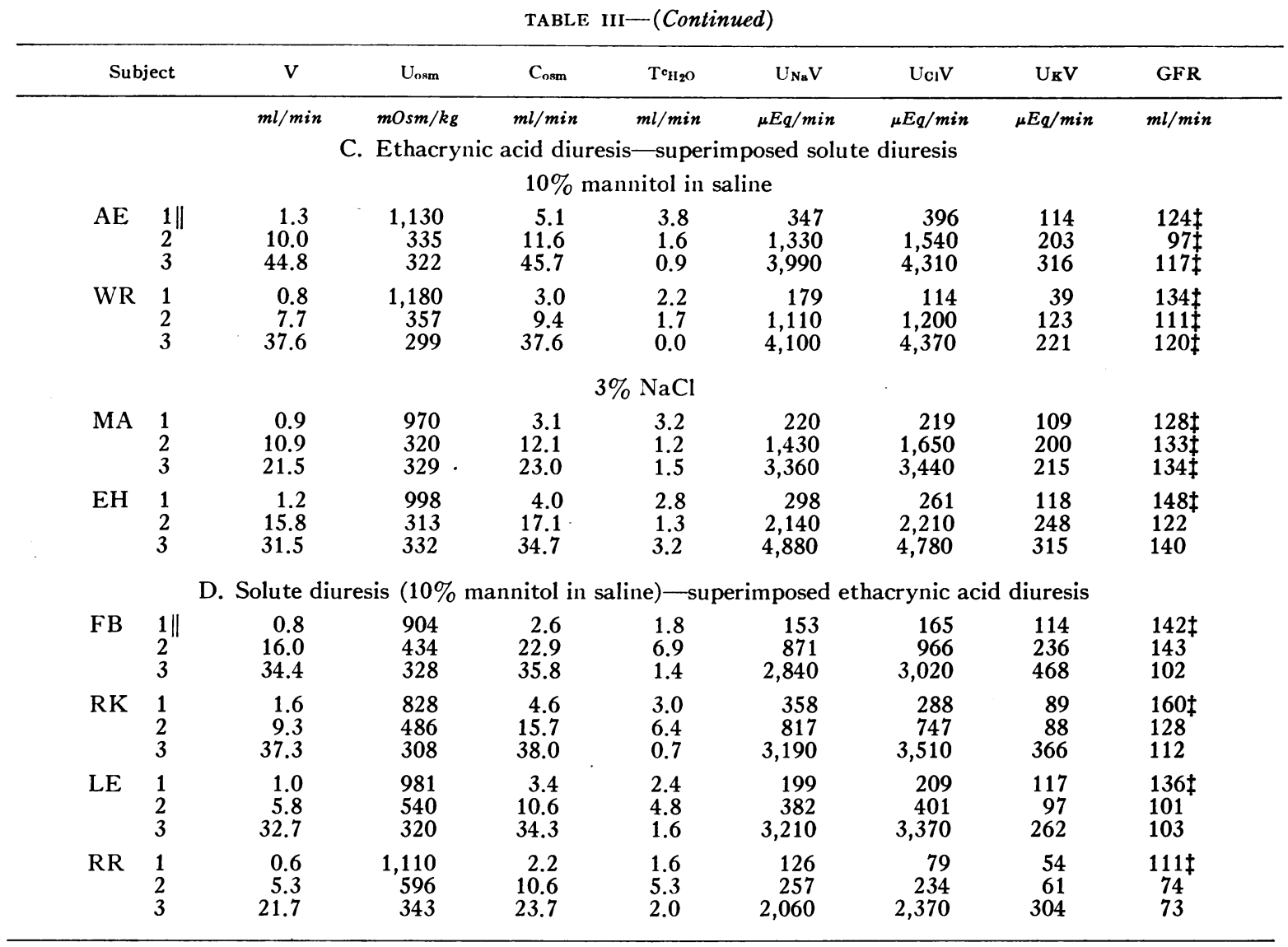

$\|$ For studies with combined ethacrynic acid and nonspecific solute diuretics, 1 refers to values before administration of any diuretics, 2 refers to values obtained during established diuresis from the first agent and just before administration of the second agent, and 3 refers to values obtained during the peak of diuretic response to both agents simultaneously.

ministration of ethacrynic acid. During the peak of diuresis, GFR fell slightly ( 2 to $18 \%$ ) in four subjects, but later, on the descending limb of the diuresis about 3 hours after the drug was administered, GFR was 10 to $30 \%$ below control values in all five experiments during water diuresis. No detectable changes in systemic blood pressure were associated with the above alterations.

\section{Studies in hydropenic subjects}

A. Control solute diuresis. All control solute diuresis studies using $10 \%$ mannitol in saline or $3 \%$ sodium chloride are summarized in Table III, A. Figure 2 illustrates the relationship between $\mathrm{T}^{\mathrm{c}}{ }_{\mathrm{H}_{2} \mathrm{O}}$ and $\mathrm{C}_{\mathrm{osm}}$ in these experiments. (A typical control experiment with mannitol also appears at the top of Figure 4.) In both types of solute diuresis, $\mathrm{T}^{\mathbf{c}} \mathrm{H}_{2} \mathrm{O}$ rose to approximately $7 \mathrm{ml}$ per minute when $\mathrm{C}_{\text {osm }}$ increased to $15 \mathrm{ml}$ per minute. When $\mathrm{C}_{\text {osm }}$ exceeded $20 \mathrm{ml}$ per minute, however, no further rise in $\mathrm{T}^{\mathrm{c}} \mathrm{H}_{2} \mathrm{O}$ occurred during mannitol diuresis; it actually decreased slightly to $5 \mathrm{ml}$ per minute when $\mathrm{C}_{\text {osm }}$ exceeded $35 \mathrm{ml}$ per minute. In contrast, in the two experiments with $3 \%$ sodium chloride, $\mathrm{T}^{\mathbf{c}} \mathrm{H}_{2} \mathrm{O}$ did not fall but continued to rise with increasing $C_{o s m}$, reaching $11 \mathrm{ml}$ per minute when $\mathrm{C}_{\text {osm }}$ exceeded $27 \mathrm{ml}$ per minute. Although the rate of rise in $\mathrm{T}^{\mathrm{c}} \mathrm{H}_{2} \mathrm{O}$ decreased moderately at high values for $\mathrm{C}_{\text {osm }}$, values for

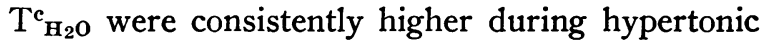
saline diuresis than in hypertonic mannitol diuresis at comparable values for $\mathrm{C}_{\text {osm }}$ above $15 \mathrm{ml}$ per minute.

B. Effects of ethacrynic acid alone (administered at low initial rates of solute excretion). Summaries of the results with ethacrynic acid alone in four subjects are contained in Table 


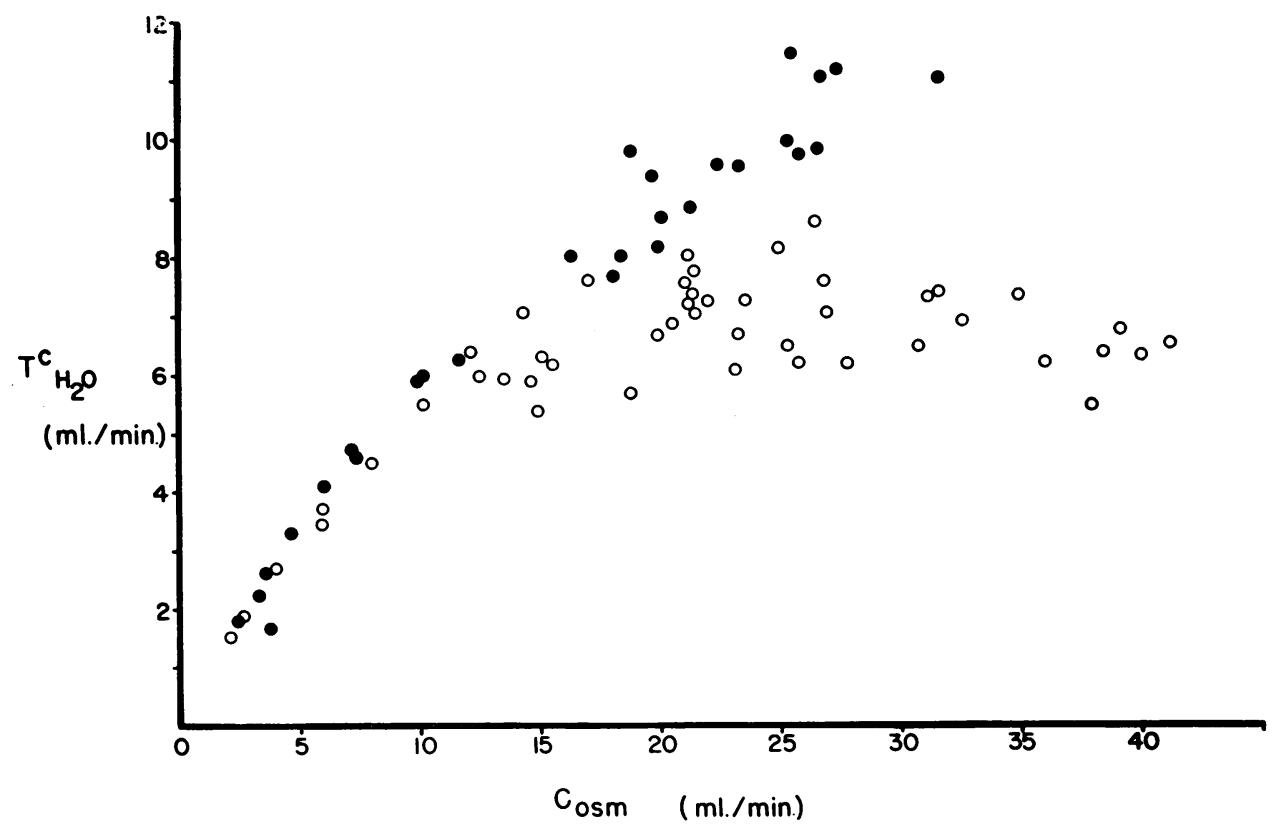

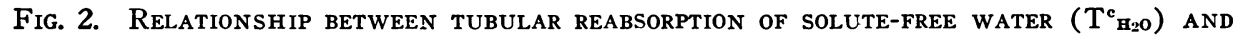
OSMOLAR CLEARANCE ( $\mathrm{C}_{\text {osm }}$ ) IN HIYDROPENIC SUBJECTS UNDERGOING OSMOTIC DIURESIS. Open circles represent three subjects undergoing hypertonic mannitol diuresis, and closed circles represent two subjects undergoing hypertonic saline diuresis. $\mathrm{T}^{\mathrm{c}} \mathrm{H}_{2} \mathrm{O}$ was consistently higher during hypertonic saline diuresis when $\mathrm{C}_{\text {osm }}$ exceeded $15 \mathrm{ml}$ per minute.

III, B. A typical study is illustrated in Figure 3 showing the effects on $\mathrm{V} ; \mathrm{U}_{\text {osm }} / \mathrm{P}_{\text {osm }} ; \mathrm{C}_{\text {osm }}$; $\mathrm{T}^{\mathbf{c}} \mathrm{H}_{2} \mathrm{O}$; sodium, chloride, and potassium excretion; and $\mathrm{C}_{\mathbf{I n}}$. As in hydrated subjects, ethacrynic acid produced predominantly a natriuresis and chloruresis, although the magnitude of the saluresis was less than during water diuresis. Maximal sodium excretion varied from 1,070 to $1,520 \mu \mathrm{Eq}$ per minute. The rise in potassium excretion was similar to that seen in hydrated subjects; a moderate decrease in GFR was also noted.

The most significant results of this study were the alterations produced in the renal concentrating mechanism. In contrast to the control solute diuresis studies, $\mathrm{T}^{\mathbf{c}_{\mathrm{H}_{2} \mathrm{O}}}$ fell rapidly below control values with the onset of diuretic action. This fall in $\mathrm{T}^{\mathrm{c}} \mathrm{H}_{2} \mathrm{O}$ caused by ethacrynic acid continued well beyond the maximal saluresis, reaching values as low as 0.6 to $1.0 \mathrm{ml}$ per minute when $\mathrm{C}_{\text {osm }}$ was between 7.0 and $12.3 \mathrm{ml}$ per minute.

C. Ethacrynic acid diuresis with superimposed solute diuresis. These studies are summarized in Table III, C. A typical experiment in which ethacrynic acid was followed by hypertonic man- nitol is shown at the bottom of Figure 4. The relationships between $\mathrm{T}^{c_{H_{2}} \mathrm{O}}$ and $\mathrm{C}_{\mathrm{osm}}$ in four experiments in which either 3\% saline (two subjects) or hypertonic mannitol (two subjects) was administered after the onset of action of ethacrynic acid are illustrated in Figure 5, A.

As in the previous group of studies, in every subject $\mathrm{T}^{\mathbf{c}}{ }_{\mathrm{H}_{2} \mathrm{O}}$ decreased below control values as $\mathrm{C}_{\text {osm }}$ increased due to ethacrynic acid. After hypertonic mannitol was begun, $\mathrm{T}^{\mathrm{c}} \mathrm{H}_{2} \mathrm{O}$ rose slightly and transiently in one subject (AE) and then fell progressively to values less than $1 \mathrm{ml}$ per minute as $\mathrm{C}_{\text {osm }}$ increased. In subject WR, whose study is illustrated in the lower chart in Figure 4, despite the administration of mannitol, $\mathrm{T}^{\mathbf{c}} \mathbf{H}_{2} \mathrm{O}$ progressively fell to zero. In both experiments with $3 \%$ saline, $\mathrm{T}_{\mathbf{H}_{2} \mathrm{O}}^{\mathrm{c}_{2}}$ increased slightly to 3.2 $\mathrm{ml}$ per minute at a $\mathrm{C}_{\mathrm{osm}}$ of $34.7 \mathrm{ml}$ per minute in subject $\mathrm{EH}$, but did not rise above $1.5 \mathrm{ml}$ per minute in the other subject (MA). Thus, compared to the control studies, ethacrynic acid blocked the rise in $\mathrm{T}_{\mathrm{H}_{2} \mathrm{O}}$ normally occurring with osmotic diuresis during hydropenia.

D. Solute diuresis (10\% mannitol in saline) 

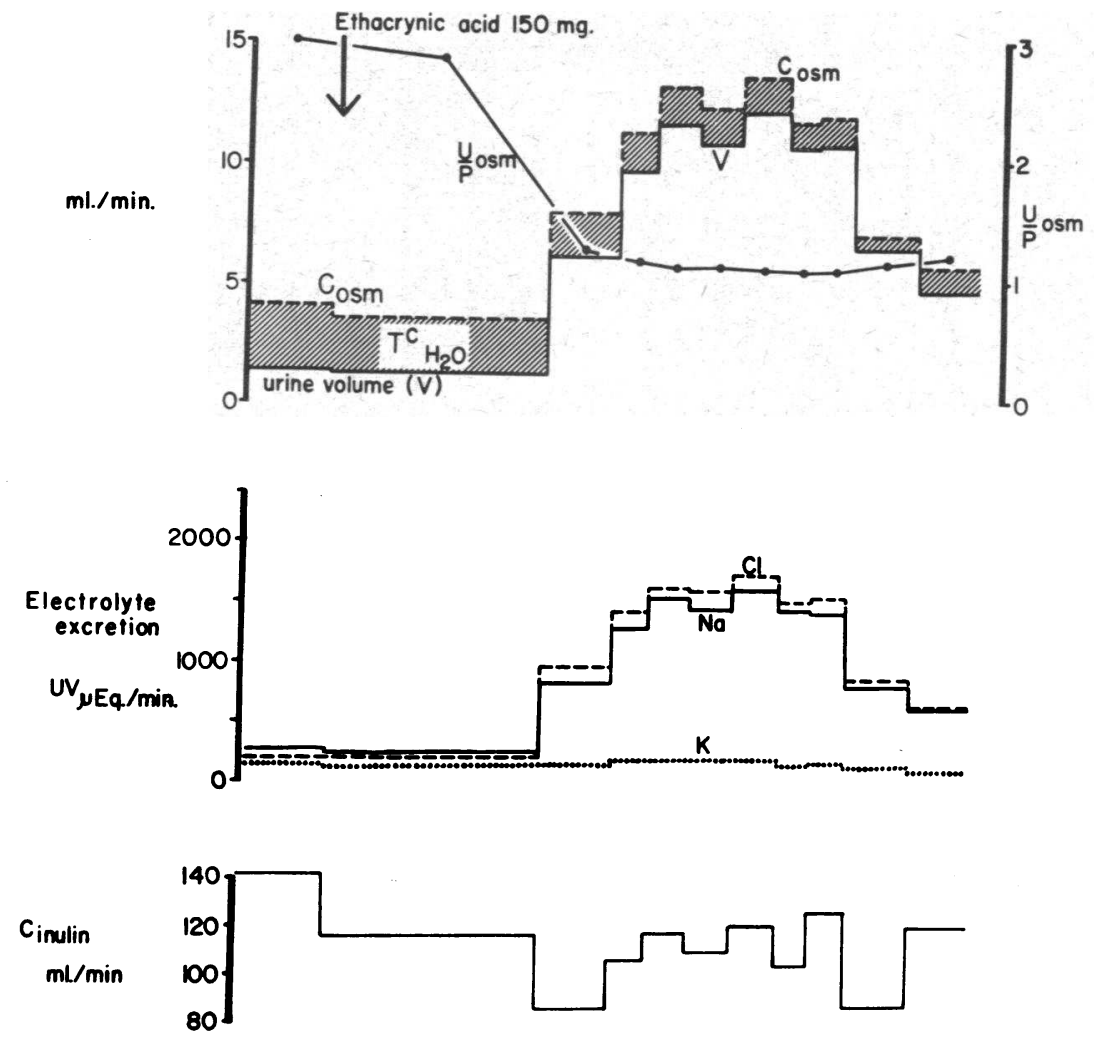

Time (min.)

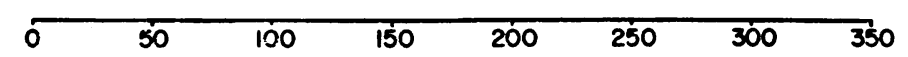

Fig. 3. EthaCrynic aCid IN a NORMal hydropenic SUBJeCt (eH). Effects on urine flow $(V)$, tubular reabsorption of solute-free water $\left(\mathrm{T}^{\mathrm{c}} \mathbf{H}_{20} \mathrm{O}\right)$, osmolar clearance $\left(\mathrm{C}_{\mathrm{osm}}\right)$, electrolyte excretion, and inulin clearance. As $\mathrm{C}_{\mathrm{osm}}$ increased, $\mathrm{T}^{\mathrm{c}}{ }_{\mathrm{H}_{2} \mathrm{O}}$ progressively fell from a control value of $2.7 \mathrm{ml}$ per minute to a minimal value of $0.6 \mathrm{ml}$ per minute.

with superimposed ethacrynic acid diuresis. These studies are summarized in Table III, D. In Figure 4, the upper and middle charts illustrate two different experiments in the same subject. The upper chart shows a control study with $10 \%$ mannitol in saline in subject $\mathrm{RK}$ in which $\mathrm{T}^{\mathrm{c}} \mathrm{H}_{2} \mathrm{O}$ remained relatively constant between 6.6 and $7.1 \mathrm{ml}$ per minute at values of $\mathrm{C}_{\text {osm }}$ varying from 10 to $41 \mathrm{ml}$ per minute. In the experiment represented in the middle chart, after a mannitol diuresis was established and $\mathrm{T}^{\mathbf{c}} \mathrm{H}_{2} \mathrm{O}$ had approached its maximal value at a $\mathrm{C}_{\text {osm }}$ of $15 \mathrm{ml}$ per minute, ethacrynic acid was given. In 50 minutes $\mathrm{T}^{c_{\mathrm{H}_{2}} \mathrm{O}}$ had decreased to $4.3 \mathrm{ml}$ per minute at a $\mathrm{C}_{\text {osm }}$ of 30 $\mathrm{ml}$ per minute, and later when $\mathrm{C}_{\text {osm }}$ was $38 \mathrm{ml}$ per minute, $\mathrm{T}^{\mathrm{c}}{ }_{\mathrm{H}_{2} \mathrm{O}}$ reached $0.7 \mathrm{ml}$ per minute. At comparable values of $\mathrm{C}_{\mathrm{osm}}$ in the control experi- ment, $\mathrm{T}^{\mathbf{c}_{\mathrm{H}_{2} \mathrm{O}}}$ exceeded $6 \mathrm{ml}$ per minute. There was also a difference between the curves representing the $U_{\text {osm }} / P_{\text {osm }}$ ratios in the two experiments. These curves were almost identical until the effects of ethacrynic acid became manifest in the second study. After this, the $U_{\text {osm }} / P_{\text {osm }}$ ratio decreased rapidly towards 1.0 (i.e., the urine was virtually isotonic to blood). In the control mannitol diuresis, however, even at a $\mathrm{C}_{\text {osm }}$ of 41 $\mathrm{ml}$ per minute, the $\mathrm{U}_{\text {osm }} / \mathrm{P}_{\text {osm }}$ ratio was 1.20.

In the other three experiments utilizing the same protocol, the results were qualitatively the same (Table III, D). Figure 5, B illustrates the relationship between $\mathrm{T}^{\mathrm{c}}{ }_{\mathrm{H}_{2} \mathrm{O}}$ and $\mathrm{C}_{\text {osm }}$ during these studies. $\mathrm{T}^{\mathbf{c}} \mathbf{H}_{2} \mathrm{O}$ during the initial mannitol diuresis reached values of 4.89 to $6.90 \mathrm{ml}$ per minute at values of $C_{\text {osm }}$ varying from 10.6 to $22.9 \mathrm{ml}$ per 


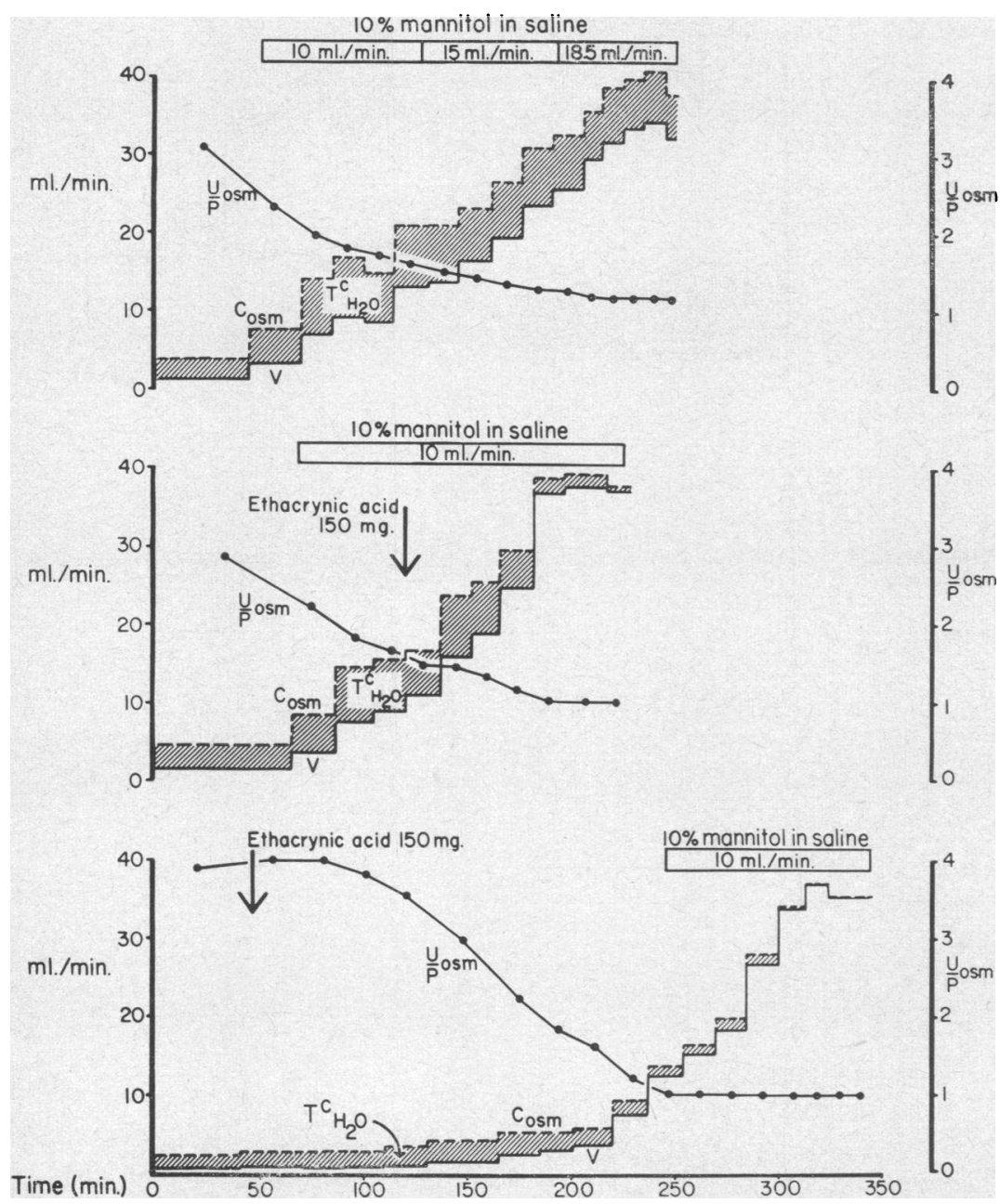

Fig. 4. Three experiments during hydropenia. The upper chart illustrates the effects of hypertonic mannitol diuresis on tubular reabsorption of solute-free water $\left(\mathrm{T}^{\mathrm{c}} \mathrm{H}_{2} \mathrm{O}\right)$ in subject $\mathrm{RK}$. $\mathrm{T}^{\mathrm{c}}{ }_{\mathrm{H}_{2} \mathrm{O}}$ remained relatively constant between 6.6 and $7.1 \mathrm{ml}$ per minute while osmolar clearance $\left(C_{o s m}\right.$ ) varied from 10 to $41 \mathrm{ml}$ per minute. The middle chart shows another experiment in subject RK in which ethacrynic acid was given during a mannitol diuresis. In contrast to the control experiment, $\mathrm{T}^{\mathbf{c}}{ }_{\mathrm{H}_{2} \mathrm{O}}$ fell markedly to a value of $0.7 \mathrm{ml}$ per minute. The lower chart illustrates the inability of hypertonic mannitol to elevate $\mathrm{T}^{\circ} \mathrm{H}_{2} \mathrm{O}$ during a saluresis due to ethacrynic acid. At the end of the study, the urine was isotonic to blood. U/P osm = urine osmolality/serum osmolality.

minute. During superimposed ethacrynic acid diuresis, $\mathrm{T}^{\mathrm{c}} \mathrm{H}_{2} \mathrm{O}$ fell below $2 \mathrm{ml}$ per minute in all four subjects at values of $\mathrm{C}_{\mathrm{osm}}$ from 23.7 to 39.4 $\mathrm{ml}$ per minute.

Thus the administration of ethacrynic acid at either low or high initial rates of solute excretion had essentially the same effect on the renal concentrating mechanism. $\quad \mathrm{T}^{\mathbf{c}}{ }_{\mathrm{H}_{2} \mathrm{O}}$ decreased markedly, often to values less than $1.0 \mathrm{ml}$ per minute while the urine became virtually isotonic with blood. In no instance, however, did ethacrynic acid during hydropenia result in the excretion of urine hypotonic to blood. Figure 6 summarizes the effects of ethacrynic acid on the $U_{\text {osm }} / P_{\text {osm }}$ ratio in all hydropenic studies compared to the effects of hypertonic mannitol or saline. In this chart, it is clear that once ethacrynic acid begins to show its effects, no matter what the rate of 

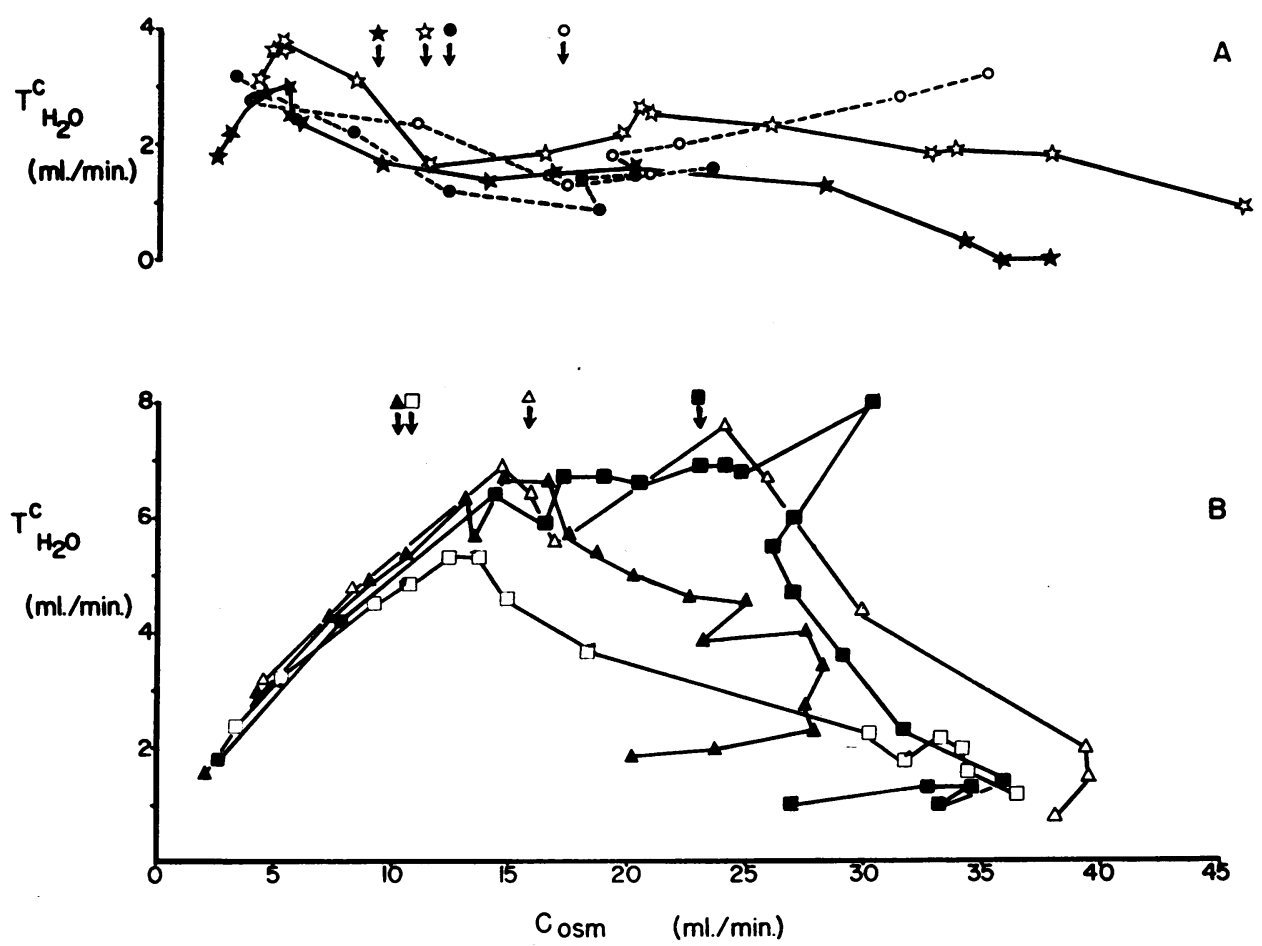

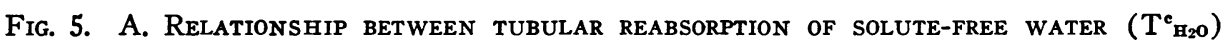
AND OSMOLAR CLEARANCE ( $C_{o s m}$ ) IN FOUR EXPERIMENTS DURING HYDROPENIA WHEN A NONSPECIFIC OSMOTIC DIURESIS WAS SUPERIMPOSED ON A DIURESIS OWING TO ETHACRYNIC ACID. Each curve represents one subject. The first point of each curve represents the control value just before administration of ethacrynic acid. The arrows indicate the point at which an infusion of hypertonic mannitol (star symbols) or hypertonic saline (circle symbols) was begun. The rise in $\mathrm{T}_{\mathrm{H}_{2} \mathrm{O}}^{\mathrm{C}}$ normally seen with solute diuresis did not occur.

B. RELATIONSHIP BETWEEN $T^{\mathbf{c}} \mathrm{H}_{2} \mathrm{O}$ AND Cosm IN FOUR EXPERIMENTS DURING HYDROPENIA WHEN ETHACRYNIC ACID WAS ADMINISTERED DURING AN ESTABLISHED MANNITOL DIURESIS. Each curve represents one subject. The first point of each curve represents the control value just before beginning the mannitol infusion. The arrows indicate the point at which ethacrynic acid was given. With onset of action of ethacrynic acid, $\mathrm{T}^{\mathrm{c}} \mathrm{H}_{2 \mathrm{O}}$ fell markedly despite a rising $\mathrm{C}_{\mathrm{osm}}$; the low values of $\mathrm{T}^{\mathrm{c}} \mathrm{H}_{20} \mathrm{O}$ persisted even as $\mathrm{C}_{\text {osm }}$ was decreasing.

solute excretion, the kidneys are unable to concentrate the urine.

\section{Discussion}

From these studies, it is apparent that ethacrynic acid has a definite effect on the renal processes of dilution and concentration. During maximal water diuresis, the increase in $\mathrm{C}_{\text {osm }}$ (predominantly due to a sodium chloride diuresis) was proportionately greater than the rise in urine flow. Hence, $\mathrm{C}_{\mathrm{H}_{2} \mathrm{O}}$ was reduced in association with a rise in $U_{\text {osm. }}$. This effect of the drug could be due to a locus of action in either of the two diluting sites-the ascending limb of Henle's loop or the distal tubule. An action solely in the distal tubule affecting dilution would be expected to increase solute excretion without appreciably increasing urine flow (14). Consequently, if ethacrynic acid were to act in the distal tubule, another simultaneous effect would have to be postulated at a site where solute is reabsorbed isosmotically, such as the proximal tubule, to account for the significant rise in urine volume after the drug. As pointed out by several investigators $(13,14,19)$, action of a drug solely in the proximal convoluted tubule could not explain a decrease in $\mathrm{C}_{\mathrm{H}_{2} \mathrm{O}}$. Like the control studies with mannitol, a proximally acting drug would be expected to increase $\mathrm{C}_{\mathrm{H}_{2} \mathrm{O}}$ in contrast to our observations with ethacrynic acid. 


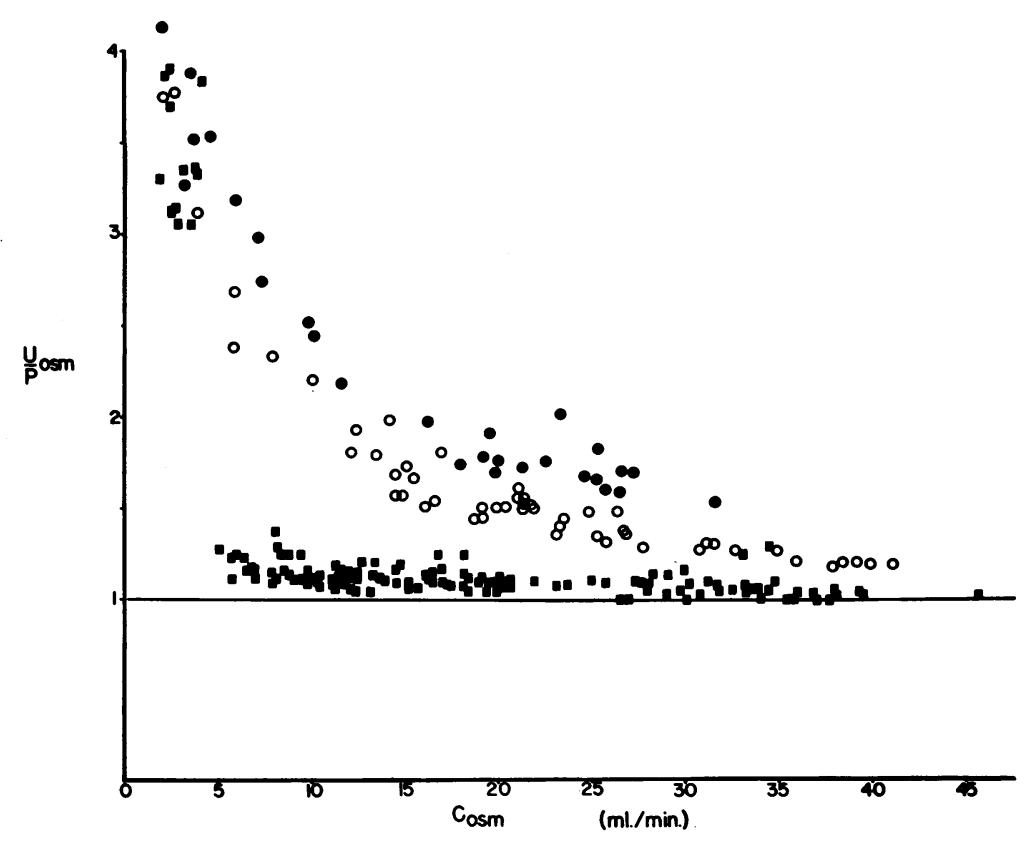

Fig. 6. EFFECTS OF ETHACRYNIC ACID (SOLID SQUARES), HYPERTONIC MANNITOL (OPEN CIRCLES), AND HYPERTONIC SALINE (CLOSED CIRCLES) ON URINE OSMOLALITY TO SERUM OSMOLALITY RATIO (U/P osm). The control points for all experiments are in the upper left portion of the chart. The points representing ethacrynic acid are taken from all hydropenic experiments after onset of drug action. Once the effects of ethacrynic acid are manifest, a virtually isotonic urine is excreted at all rates of solute excretion.

On the other hand, an effect in the ascending limb of Henle's loop could account for the decrease in $\mathrm{C}_{\mathrm{H}_{2} \mathrm{O}}$ and, in large part, the rise in both solute excretion and urine volume. According to micropuncture studies in the rat, approximately 10 to $15 \%$ of filtered water is reabsorbed in the loop of Henle (23). Solute (i.e., sodium chloride) reabsorption in the loop is greater than water reabsorption, corresponding to approximately 14 to $21 \%$ of filtered sodium. ${ }^{2}$ A drug that would completely inhibit sodium reabsorption in the ascending limb during maximal water diuresis would be expected to cause 1 ) predominantly a sodium chloride diuresis, 2) a decrease in $\mathrm{C}_{\mathrm{H}_{2} \mathrm{O}}$ but not to 0 since a more distal diluting site would still be intact, and 3) a rise both in solute excretion and urine volume in relatively hypertonic proportions. Ethacrynic acid appears to meet these requirements qualitatively. During water diuresis, maximal sodium excretion due to etha-

2 The $\mathrm{U}_{\mathrm{osm}} / \mathrm{P}_{\mathrm{osm}}$ ratio in the early distal tubule is assumed to be 0.7 (23). crynic acid was 13 to $15 \%$ of the estimated filtered load. Obviously, quantitative comparison of our data with rat micropuncture data is not possible. The rise in potassium, titratable acid, and ammonium excretion following ethacrynic acid suggests that sodium reabsorption occurred distal to the loop of Henle (24-36). Hence, a portion of sodium rejected proximal to the distal tubule and collecting duct would not have been excreted.

Detailed studies on hydropenic subjects were performed to localize further the site of action of ethacrynic acid. If the drug impaired dilution by an action distal to the loop of Henle, then $\mathrm{T}^{\mathrm{c}}{ }_{\mathrm{H}_{2} \mathrm{O}}$ might be expected to increase or remain unchanged $(14,18)$. On the other hand, inhibition of sodium reabsorption in the ascending limb would disrupt the countercurrent multiplier system and prevent the hypertonic accumulation of medullary solute. Therefore, $\mathrm{T}^{\mathbf{c}} \mathbf{H}_{2} \mathrm{O}$ would decrease, since the osmotic gradient between the medulla and collecting duct would be markedly reduced or obliterated. Such indeed was the case 
after ethacrynic acid. When the drug was administered at either low or high initial rates of solute excretion, $\mathrm{T}_{\mathrm{H}_{2} \mathrm{O}}^{\mathbf{O}}$ consistently decreased regardless of its preceeding value. In several subjects $\mathrm{T}_{\mathrm{H}_{2} \mathrm{O}}$ fell to less than $1 \mathrm{ml}$ per minute and in one subject reached 0 .

These results were in striking contrast to the control studies of nonspecific solute diuresis with hypertonic mannitol or saline. In the latter experiments, increasing quantities of sodium entering the loop from the proximal tubule were available for reabsorption in the ascending limb. Thus, more osmotically active solute accumulated in the hypertonic medulla to produce greater net movement of water into the medulla from the large volume of isotonic collecting duct urine. Similar to observations by other investigators $(14,16-18)$, an apparent maximum or ceiling for $\mathrm{T}^{\mathrm{c}} \mathrm{H}_{2} \mathrm{O}$ was observed in the mannitol experiments. In the two control studies with $3 \%$ saline, however, $\mathrm{T}_{\mathrm{H}_{2} \mathrm{O}}$ was still rising at a $\mathrm{C}_{\mathrm{osm}}$ of $27 \mathrm{ml}$ per minute. This suggests that mannitol, in contrast to saline, by retarding tubular water reabsorption and lowering the sodium concentration, may have an inhibitory effect on active sodium transport in the loop.

Perhaps the most critical experiments during hydropenia were those in which hypertonic mannitol or saline was administered during an established diuresis caused by ethacrynic acid. Once the effects of ethacrynic acid were manifest and $\mathrm{T}^{\mathbf{H}_{\mathbf{H}_{2} \mathrm{O}}}$ had fallen below control values, the superimposition of an osmotic diuresis could not significantly raise $\mathrm{T}_{\mathbf{H}_{2} \mathrm{O}}$. This suggests that, even though increasing quantities of sodium were presented to the loop, active transport into the medulla was blocked by the drug, and the countercurrent multiplier system was rendered ineffective. Higher values for $\mathrm{T}_{\mathbf{H}_{2} \mathrm{O}}$ after hypertonic saline than after hypertonic mannitol suggests that some sodium reabsorption may still have occurred in the ascending limb. This may reflect the higher intratubular sodium concentration presented to the loop with hypertonic saline diuresis than during mannitol diuresis, or incomplete block in active sodium reabsorption due to submaximal dosage of ethacrynic acid, or both.

Another possible explanation for the impairment in renal concentrating ability is that ethacrynic acid in some way interfered with the ac- tion of vasopressin $(\mathrm{ADH})$. This would necessitate postulating two different actions of the drug, one inhibiting sodium chloride transport in the proximal, or distal nephron, or both, and one inhibiting directly or indirectly the movement of water along transtubular osmotic gradients in the distal nephron. The possibility of interference with the action of $\mathrm{ADH}$ appears to be very unlikely; under conditions of impaired distal tubular permeability to water and high rates of intratubular urine flow, if solute removal were to continue normally in the loop of Henle, the excretion of a hypotonic urine would be anticipated. In none of the hydropenic studies, even at values of $\mathrm{C}_{\mathrm{osm}}$ exceeding $40 \mathrm{ml}$ per minute, was a hypotonic urine produced after ethacrynic acid. In contrast, in clinical or experimental states believed to be associated with impaired distal tubular perneability to water (such as hypercalcemia and hypercalciuria), moderately high rates of flow of distinctly hypotonic urine have occurred in the presence of maximal quantities of vasopressin $(27,28)$.

It is theoretically possible that a locus of action of the drug on solute transport in the collecting duct could have contributed to some of its effects on dilution and concentration. Klümper, Ullrich, and Hilger (29) have demonstrated in the hamster that sodium is reabsorbed from the collecting duct urine. Studies of Jaenike and Berliner suggest that chloride is also removed (30). Evidence is lacking that the salt transported out of the collecting duct contributes to the countercurrent system. Micropuncture studies in rodents have suggested that some degree of urinary dilution may be achieved in the collecting duct (9, 10). These movements of solute, however, although probably important in the regulation of sodium excretion, apparently make a relatively minor contribution to the over-all processes of dilution and concentration. Compared to the magnitude of the changes observed in our studies, it is most unlikely that the sole or most important action of ethacrynic acid is in the collecting duct, if it acts there at all.

Thus, the evidence strongly suggests that a major site of action of ethacrynic acid is in the loop of Henle. Inhibition of sodium chloride reabsorption in the ascending limb impairs a major component of the diluting mechanism and, by 
blocking medullary solute accumulation, disrupts the concentrating mechanism. Our data do not eliminate the possibility of an additional action of the drug in the proximal convoluted tubule. Although the increment of saluresis in our studies approached the magnitude of solute estimated to be reabsorbed in the loop, it is possible that under other experimental or clinical conditions a greater solute diuresis might be demonstrable. The final solution to this problem will have to come through micropuncture studies in the dog or monkey, since the drug is ineffective in the rodent $(3,4)$.

While this study was in progress, a preliminary report on the use of ethacrynic acid in thirteen edematous patients was presented by Nash and associates (31). Their studies, similar to ours, revealed a decreased $\mathrm{C}_{\mathrm{H}_{2} \mathrm{O}}$ during water diuresis, a maximal tubular rejection of sodium of $15 \%$, and a moderate reduction in GFR because of the drug. No studies during hydropenia were reported.

The clear-cut action of ethacrynic acid on both

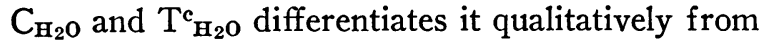
the other major diuretics. Carbonic anhydrase inhibitors such as acetazoleamide produce an increase in $\mathrm{C}_{\mathrm{H}_{2} \mathrm{O}}$ with increasing solute excretion $(14,32,33)$, an effect opposite to that of ethacrynic acid. The effects of chlorothiazide on urinary dilution and concentration have been studied in humans and dogs by Heinemann, Demartini, and Laragh (19) and Earley, Kahn, and Orloff (14). Like ethacrynic acid, chlorothiazide diminishes $\mathrm{C}_{\mathrm{H}_{2} \mathrm{O}}$ during maximal water diuresis, although in humans the magnitude of the decrease with benzothiadiazine compounds does not appear to be so great as with ethacrynic acid (19). In contrast, however, chlorothiazide had no effect on $\mathrm{T}^{\mathrm{c}} \mathrm{H}_{2} \mathrm{O}$ in one hydropenic human subject (19) and produced a greater increase in $\mathrm{T}_{\mathrm{H}_{2} \mathrm{O}}$ than did mannitol diuresis in dogs at high rates of solute excretion (14). Because of these observations, Earley, Kahn, and Orloff (14) postulated an action of chlorothiazide at the diluting site in the distal nephron distal to the loop of Henle. Interpretation of the data in the literature on studies with organomercurial diuretics on renal dilution and concentration with respect to site of action is more difficult. In some studies, impairment in the concentrating mechanism has been reported $(34,35)$, and in some, enhancement of $\mathrm{C}_{\mathrm{H}_{2} \mathrm{O}}$ with meralluride has been observed (19, 36). More recently, however, Becker and Ginn (15) in dogs and Goldstein, Levitt, Hauser, and Polimeros in man (13) have demonstrated that nontheophylline-containing mercurials have no observable effect on $\mathrm{C}_{\mathrm{H}_{2} \mathrm{O}}$. Although a site of action in the loop of Henle by mercurials is possible, strong evidence for this is lacking. The equivocal effects of mercurial diuretics on both $\mathrm{T}^{\mathrm{c}} \mathrm{H}_{2} \mathrm{O}$ and $\mathrm{C}_{\mathrm{H}_{2} \mathrm{O}}$ are in striking contrast to the definite effects of ethacrynic acid on these variables.

\section{Summary}

The effects of ethacrynic acid, a new orally active diuretic agent, on the renal mechanisms of dilution and concentration were studied. Twentyseven acute experiments were performed on eighteen normal human subjects and two patients with diabetes insipidus. The experimental conditions included water diuresis and hydropenia with and without superimposed osmotic diuresis.

Ethacrynic acid caused primarily a natriuresis and chloruresis and had a distinct effect on both free water clearance $\left(\mathrm{C}_{\mathrm{H}_{2} \mathrm{O}}\right)$ during maximal water diuresis and tubular reabsorption of solutefree water $\left(\mathrm{T}^{\mathrm{c}} \mathrm{H}_{2} \mathrm{O}\right)$ during hydropenia. In maximally hydrated normal subjects and in patients with diabetes insipidus, $\mathrm{C}_{\mathbf{H}_{2} \mathrm{O}}$ was significantly decreased as osmolar clearance increased, in contrast to mannitol diuresis. The drug also caused a moderate reduction in glomerular filtration rate and an increase in the excretion of potassium and hydrogen ions.

During hydropenia, $\mathrm{T}^{\mathbf{c}}{ }_{\mathrm{H}_{2} \mathrm{O}}$ was markedly decreased at both low and high rates of solute excretion. Hypertonic mannitol or saline diuresis, which in themselves increased $\mathrm{T}^{\mathbf{c}}{ }_{\mathrm{H}_{2} \mathbf{O}}$, when superimposed on a diuresis due to ethacrynic acid, could not raise $\mathrm{T}_{\mathbf{H}_{2} \mathrm{O}}$ to normal levels. Characteristically, during the peak of diuresis caused by the drug, a virtually isotonic urine was excreted at various levels of solute clearance, and this effect persisted even after the peak of saluresis.

These results differentiate ethacrynic acid qualitatively from other diuretic agents and suggest that an important locus of action is in the ascending limb of the loop of Henle where sodium chloride is reabsorbed in excess of water. This hy- 
pothesis would explain the effects of ethacrynic acid on both the renal diluting and concentrating mechanisms and also could account in large part for the type and magnitude of the solute diuresis following administration of the drug.

\section{Acknowledgments}

The authors thank Dr. J. Russell Elkinton for his helpful criticism of the manuscript and his support throughout this study. We acknowledge the support and encouragement of the Research Division of Merck Sharp \& Dohme. We are grateful for the technical assistance of Dolores Metz, George Paden, Edward K. Brown, Mary Hedwig Bowman, Lidia Kosolapovs, Leonids Kosolapovs, Katherine Wishnevski, Carolyn L. Penta, and Marcia A. Junad.

\section{References}

1. Goldberg, M., D. K. McCurdy, E. L. Foltz, and L. W. Bluemle, Jr. Preliminary studies in man on the renal site of action of ethacrynic acid: a new potent saluretic agent. Proc. 2nd International Congress of Nephrology. In press.

2. Schultz, E. M., E. J. Cragoe, Jr., J. B. Bicking, W. A. Bolhofer, and J. M. Sprague. $\alpha, \beta$-Unsaturated ketone derivatives of aryloxyacetic acids, a new class of diuretics. J. med. pharm. Chem. $1962,5,660$.

3. Baer, J. E., H. F. Russo, J. K. Michaelson, and K. H. Beyer. A new class of diuretic-saluretic agents, the $\alpha, \beta$-unsaturated ketone derivatives of aryloxyacetic acids. Pharmacologist 1962, 4, 158.

4. Baer, J. E., J. K. Michaelson, H. F. Russo, and K. H. Beyer. 2,3-dichloro-4-(2-methylenebutryl)phenoxyacetic acid (I), a novel and potent diuretic-saluretic agent. Fed. Proc. 1963, 22, 598.

5. Foltz, E. L. Preliminary clinical observations with an aryloxyacetic acid diuretic. Fed. Proc. 1963, 22, 598.

6. Melvin, K. E. W., R. O. Farrelly, and J. D. K. North. Ethacrynic acid: a new oral diuretic. Brit. med. J. 1963, 22, 1521.

7. Gottschalk, C. W. Micropuncture studies of tubular function in the mammalian kidney. Physiologist $1961,4,35$.

8. Ullrich, K. J., K. Kramer, and J. W. Boylan. Present knowledge of counter-current system in the mammalian kidney. Progr. cardiovasc. Dis. 1961, 3, 395.

9. Wirz, H. Der osmotische Druck in den corticalen Tubuli der Rattenniere. Helv. physiol. pharmacol. Acta 1956, 14, 353.

10. Gottschalk, C. W., and M. Mylle. Micropuncture study of the mammalian urinary concentrating mechanism; evidence for the countercurrent hypothesis. Amer. J. Physiol. 1959, 196, 927.
11. Orloff, J., H. N. Wagner, Jr., and D. G. Davidson. The effect of variations in solute excretion and vasopressin dosage on the excretion of water in the dog. J. clin. Invest. 1958, 37, 458.

12. De Wardener, H. E., and F. del Greco. The influence of solute excretion rate on the production of a hypotonic urine in man. Clin. Sci. 1955, 14, 715.

13. Goldstein, M. H., M. F. Levitt, A. D. Hauser, and D. Polimeros. Effect of meralluride on solute and water excretion in hydrated man: comments on site of action. J. clin. Invest. 1961, 40, 731.

14. Earley, L. E., M. Kahn, and J. Orloff. The effects of infusions of chlorothiazide on urinary dilution and concentration in the dog. J. clin. Invest. 1961, 40, 857.

15. Becker, E. L., and H. E. Ginn. Free water excretion in normal dogs. Amer. J. Physiol. 1962, 202, 1131.

16. Zak, G. A., C. Brun, and H. W. Smith. The mechanism of formation of osmotically concentrated urine during the antidiuretic state. J. clin. Invest. 1954, 33, 1064.

17. Raisz, L. G., W. Y. W. Au, and R. L. Scheer. Studies on the renal concentrating mechanism. IV. Osmotic diuresis. J. clin. Invest. 1959, 38, 1725.

18. Porush, J. G., M. H. Goldstein, G. M. Eisner, and M. F. Levitt. Effect of organomercurials on the renal concentrating operation in hydropenic man: comments on site of action. J. clin. Invest. 1961, 40, 1475.

19. Heinemann, H. O., F. E. Demartini, and J. H. Laragh. The effect of chlorothiazide on renal excretion of electrolytes and free water. Amer. J. Med. 1959, 26, 853.

20. Cotlove, E., H. V. Trantham, and R. L. Bowman. An instrument and method for automatic, rapid, accurate, and sensitive titration of chloride in biological samples. J. Lab. clin. Med. 1958, 51, 461.

21. Bonsnes, R. W., and H. H. Taussky. On the colorimetric determination of creatinine by the Jaffe reaction. J. biol. Chem. 1945, 158, 581.

22. Walser, M., D. G. Davidson, and J. Orloff. The renal clearance of alkali-stable inulin. J. clin. Invest. $1955,34,1520$.

23. Lassiter, W. E., C. W. Gottschalk, and M. Mylle. Micropuncture study of net transtubular movement of water and urea in nondiuretic mammalian kidney. Amer. J. Physiol. 1961, 200, 1139.

24. Berliner, R. W., T. J. Kennedy, Jr., and J. G. Hilton. Renal mechanisms for excretion of potassium. Amer. J. Physiol. 1950, 162, 348.

25. Ullrich, K. J., H. H. Hilger, and J. K. Klümper. Sekretion von Ammonumionen in den Sammelrohren der Säugtierniere. Pflügers Arch. ges. Physiol. 1958, 267, 244.

26. Ullrich, K. J., F. W. Eigler, and G. Pehling. Sekretion von Wasserstoffionen in den Sammelrohren der Säugetierniere. Pflügers Arch. ges. Physiol. 1958, 267, 491. 
27. Epstein, F. H., D. Beck, F. A. Carone, H. Levitin, and A. Manitius. Changes in renal concentrating ability produced by parathyroid extract. J. clin. Invest. 1959, 38, 1214.

28. Gill, J. R., Jr., and F. C. Bartter. On the impairment of renal concentrating ability in prolonged hypercalcemia and hypercalciuria in man. J. clin. Invest. 1961, 40, 716.

29. Klümper, J. D., K. J. Ullrich, and H. H. Hilger. Das Verhalten des Harnstoffs in den Sammelrohren der Säugetierniere. Pflügers Arch. ges. Physiol. 1958, 267, 238.

30. Jaenike, J. R., and R. W. Berliner. A study of distal renal tubular functions by a modified stop flow technique. J. clin. Invest. 1960, 39, 481.

31. Nash, H. L., W. R. Wilson, A. E. Fitz, J. M. Kioschos, and W. M. Kirkendall. Hemodynamic and renal effects of 2-3 dichloro-4-(2-methylene butyryl) phenoxyacetic acid (MK-595). Clin. Res. 1963, 11, 249.
32. Welt, L. G., D. T. Young, O. A. Thorup, Jr., and C. H. Burnett. Renal tubular phenomena under the influence of a carbonic anhydrase inhibitor (abstract). Amer. J. Med. 1954, 16, 612.

33. Counihan, T. B., B. M. Evans, and M. D. Milne. Observations on the pharmacology of the carbonic anhydrase inhibitor "Diamox." Clin. Sci. 1954, 13, 583.

34. Au, W. Y. W., and L. G. Raisz. Studies on the renal concentrating mechanism. V. Effect of diuretic agents. J. clin. Invest. 1960, 39, 1302.

35. Lambie, A. T., and J. S. Robson. The effect of mersalyl on the renal tubular reabsorption of solute free water. Clin. Sci. 1961, 20, 123.

36. Heinemann, H. O., and E. L. Becker. Effect of a mercurial diuretic on the excretion of 'free water' in diabetes insipidus. J. appl. Physiol. 1958, 12, 51. 